\title{
OPEN LETTER TO MOTHERS AGAINST DRUNK DRIVING
}

\author{
WALTER BLOCK*
}

\section{INTRODUCTION}

\begin{abstract}
Although I shall be criticizing you, even severely, please do not take this amiss. I mean your organization no harm. Quite the contrary. My two children, in their early 20's, are both new drivers. I would suffer more than I can tell you if anything were to happen to them as a result of drunken driving. I am thus a supporter of yours. I am on your side. Please take what I say as no more than friendly amendments to your plans and proposals. Some of the following critiques may sound harsh, but friends do not mince words with each other in life and death situations, and I would like you to consider me a friend of yours. We may disagree on means, but certainly not on ends.
\end{abstract}

\section{EXPANSION}

First, you must expand your scope of operations. While drunk driving is of course a major calamity on our nation's roads, it is far from the only one. There are quite a few others, even besides the «big three» of speed, weather conditions and driver error ${ }^{1}$.

* Harold E. Wirth Eminent Scholar Endowed Chair in Economics. College of Business Administration. Loyola University New Orleans

1 Peltzman, Sam, («The Effects of Automobile Safety Regulation,» Journal of Political Economy, Vol. 83, No. 4, 1975, pp. 677-725) lists the following: «Vehicle 
What difference does it really make if our children and loved ones die in a traffic fatality emanating from drunkenness or any of these other conditions? Happily there is no need to change even the MADD name if you adopt this suggestion. Only instead of the first «D» standing for «drunk» it could refer to "death,» as in Mothers Against Death Drivers. All of these things -alcohol, drugs, speeding, malfunctioning vehicles, badly engineered roads, weather conditions, whatever- are threats to our family's lives. Why single out any one of them?

A possible defense of the status quo is to borrow a leaf from the economists, and defend the present, limited, status of MADD on grounds of specialization and division of labor ${ }^{2}$. True, no one organization can do everything. Better to take on a limited agenda and do it well, than to take on too much and accomplish little or nothing.

But this insight applies only when to take on additional tasks is to dilute the focus of an enterprise. If you truly oppose fatalities only from the single cause of alcoholism, well and good. MADD as presently constituted then needs no broadening of vision. But if your goal is decrease the senseless roadway slaughter of innocents which stems from any cause, which I strongly

\footnotetext{
speed ... alcohol consumption ... the number of young drivers ... changes in drivers incomes ... the money costs of accidents ... the average age of cars ... the ratio of new cars to all cars (because it has been suggested that while drivers familiarize themselves with their new cars, accident risk may increase) ... traffic density ... expenditures on traffic-law enforcement by state highway patrols expenditures on roads ... the ratio of imports to total car; (because there is evidence that small cars are more lethal than large cars if an accident occurs) ... education of the population ... and the availability of hospital care (which might reduce deaths if injury occurs).» The list put together by the National Highway Traffic and Safety Administration is much larger. See on this http://www.nhtsa.dot.gov/. See also Traffic Safety Facts 2001 from the National Highway Traffic Safety Administration at http://www-nrd.nhtsa.dot.gov/pdf/nrd-30/NCSA/TSFAnn/TSF2001.pdf, and the Fatality Analysis Reporting System (FARS) database at http://wwwfars.nhtsa.dot.gov / queryReport.cfm?stateid =0\&year $=2001$.

${ }^{2}$ See on this Smith, Adam, An Inquiry into the Nature and Causes of the Wealth of Nations, New York: Modern Library, 1776/1965
} 
suspect is the case, then to include the contributions from other sources does not weaken the mission; on the contrary, it fortifies it.

\section{PRIVATIZATION}

My second suggestion is far more radical. Please hear me out. There are very important matters at stake. True, the highway fatality rates have been declining in recent years ${ }^{3}$. But 41,480 the number of people who perished as a result of improper automobile use in 1998, the last year for which such figures are available, is still far too high. Desperate circumstances require radical solutions.

The radical suggestion I offer is that MADD adopt as one of its major policy planks the proposal that our nation's roadways be privatized. And this includes not only the federal interstate highway system, but every by way, country road, city street and even sidewalk - wherever vehicle related deaths have occurred. Why? There are several reasons.

First, it is not at all true that speech, alcohol, drugs, etc., are ultimately responsible for vehicular death. Rather, they are only the proximate causes. The underlying explanation is that the managers of the roads, those in charge of them, have failed to deal with these problems. The reason Chrysler went broke is only indirectly related to car size, changing styles, competition, imports, the price of oil and gas, etc. This company was bankrupted because its managers failed to meet these challenges. When a

3 According to the Fatality Analysis Reporting System (FARS) of the National Highway Traffic and Safety Administration (NHTSA), for 1999, highway deaths for 1998 were 41,480; for 1997, 42,103; for 1994, 40,676; for 1993,40,115; and for $1979,51,093$. Since number of passenger miles was increasing during this time period, the actual safety improvement given by these statistics on a mile-traveled basis is understated. 
restaurant shuts down, it is not due to such proximate causes as poorly cooked food, poor service, bad location, unclean premises, etc. Rather, this circumstance is due to the fact that the owners, operators, managers of the restaurant failed to address these problems.

Second, with a system of private highways and streets, the various owners would compete with one another to provide service for their customers (including, pre eminently, safety). Those who failed, (e.g., pursued policies detrimental to the «health of children and other living things») would be forced either to change the error of their ways or go belly up. Those who saved lives by better dealing with drunkards, speeders, etc., would earn profits and thus be enabled to expand the base of their operations.

Third, this is precisely the system - privatization - that vastly outstripped that of the U.S.S.R. in providing computers, cars, clothes and a plethora of other products and services. Yet, instead of borrowing a leaf from our own success and applying it to highways, we have instead copied the discredited soviet economic system and applied it to our network of roadways. That is, our highway network is governmentally owned and managed. This is why people die like flies on these roads, and suffer from traffic congestion serious enough to try the patience of a saint (which also exacerbates casualties through road rage).

Fourth, the rules of the road that would minimize automobile accidents (this goes for most other valuable economic recipes) do not come to us from on high, imprinted on stone tablets. Rather, they have to be learned, oft-times by hard and difficult experience. The time honored and traditional capitalist way of learning is by allowing all entrepreneurs, willing to risk their own money, free rein to do exactly as they please. The ones who hit upon the best way of proceeding earn profits; those who do not either have to copy the successful, or fall by the wayside. It is precisely this, the magic of the marketplace, that has brought 
us our world-class standards of living. But this learning process cannot possibly take place when politicians, bureaucrats, and other members of the nomenklatura class determine the rules of the road, and do not lose an iota of their personal fortunes when they err in this way, or, indeed, are guilty of any other sort of highway mismanagement.

We all deplore highway casualties. But at least when they occur, let us have a system wherein someone in authority loses money thereby. There is nothing that concentrates the managerial mind more. At present, when deaths take place, there is no one in a position to ameliorate matters who suffers financially. Surely we may expect better results from a system that monetarily rewards the successful and punishes those who fail than from one which does neither.

Take a case in point. It is perhaps a truism that «speed kills.» Yet, the rate of fatalities has decreased after the elimination of the 55 -mile per hour speed limit. Some analysts have suggested that it is not the average rate of travel that is determinative, but rather the variance in speed. That is, we might all be safer with a slow lane speed requirement (both minimum and maximum) of 60 $\mathrm{mph}$, a middle lane of $70 \mathrm{mph}$ and a fast lane of $80 \mathrm{mph}$, than with the present minimum of $40 \mathrm{mph}$ and maximum of 70, typical of many highways. I don't know that answer to this question. But I do know the best way to answer it: unleash a new breed of road entrepreneurs on it. Allow each of them to address this issue as they wish. Then, using the same system we as a society have utilized to improve the quality of cars, computers and clothes, among other things, we shall find the answer.

Take another example, closer to the concerns of MADD. How best to stop driving while drinking? Heavier penalties? More emphasis on driver education? More police monitoring? Rewards for exemplary driving? Payment for joining Alcoholics Anonymous? Again, the same principles apply. Privatize the avenues of vehicular transportation, and rely upon the new 
owners, under the tutelage of the free enterprise profit and loss system, to find solutions.

One of this new breed of highway proprietors, of course, would be MADD. Under such a system a revitalized and reinvigorated MADD, as an organization, would be able to implement its own policies on drinking while driving, speeding, whatever. It would have to take its chances in competition with all other entrants into this industry, but that is the way of the market system.

At present, in contrast, under a road system that would bring a smile to the face of a Russian Commissar, there is simply no managerial role for MADD to play. Compare your situation with that of Ducks Unlimited, Western Wilderness Society, or any other environmental group. They are not relegated to the sidelines, in their analogous field, limited to offering advice, and, in a word, begging the powers that be. They can of course do these things. But they can also buy up vast tracts of land (they would be unable to do this in the U.S.S.R.) and manage them as they please $\mathrm{e}^{4}$. Why should MADD accept its present inferior status, vis a vis these other groups?

\section{CONCLUSION}

Two final points. There are those who will dismiss these suggestions as the ravings of a lunatic. They will throw up all sorts of obstacles and objections: the specter of having to place a coin in a toll box of every home you pass by in the street; of having your house surrounded by private road owners who deny to

${ }^{4}$ Anderson, Terry, and Leal, Donald R., (1991, pp. 64, 90, Free Market Environmentalism, San Francisco: Pacific Institute) mention the case of the National Audubon Society's Rainey Wildlife Sanctuary in Louisiana. When natural gas was discovered on their property, this organization chose to develop it, something of a departure from their typical reaction to such circumstances. 
access and egress; of crazy road owners who would demand weird behavior, such as forcing everyone to travel in reverse gear. However, there is a wealth of published material refuting these and all other criticisms of private highway ownership and management ${ }^{5}$. Before giving in to the «nattering nabobs of nega-

5 See on this Block, Walter, «Roads, Bridges, Sunlight and Private Property: Reply to Gordon Tullock,» Journal des Economistes et des Etudes Humaines, Vol. 8, No. 2/3, June-September 1998, pp. 315-326; Block, Walter, «Compromising the Uncompromisable: Speed, Parades, Cigarettes,» Asian Economic Review, Vol. 40, No. 1, April 1998, pp. 15-29; Block, Walter, «Private Roads, Competition, Automobile Insurance and Price Controls,» Competitiveness Review, Vol. 8, No. 1, 1998, pp. 55-64; Block, Walter, «Road Socialism,» International Journal of Value-Based Management, 1996, Vol. 9, pp. 195-207; Block, Walter, «Roads, Bridges, Sunlight and Private Property Rights,» (with Block, Matthew), Journal Des Economistes Et Des Etudes Humaines, Vol. VII, No. 2/3, June-September 1996, pp. 351-362; Block, Walter, «Public Goods and Externalities: The Case of Roads,» The Journal of Libertarian Studies, Vol. VII, No. 1, Spring 1983, pp. 1-34; Block, Walter, «Theories of Highway Safety,» Transportation Research Record, \#912, 1983, pp. 7-10; Block, Walter, "Congestion and Road Pricing," The Journal of Libertarian Studies, Vol. IV, No. 3, Fall 1980, pp. 299-330; Block. Walter, «Free Market Transportation: Denationalizing the Roads,» Journal of Libertarian Studies: An Interdisciplinary Review, Vol. III, No. 2, Summer 1979, pp. 209-238; anthologized in The Libertarian Reader, ed. Tibor R. Machan, Totowa, New Jersey: Rowman \& Littlefield, 1982, pp. 164-183; Cadin, Michelle, and Block, Walter, (1997), «Privatize the Public Highway System,» The Freeman, February, Vol. 47, No. 2., pp. 96-97; Cobin, John, M. (1999), Market Provisions of Highways: Lessons from Costanera Norte. Planning and Markets, Volume 2, Number 1; Gunderson, Gerald, «Privatization and the 19thCentury Turnpike,» Cato Journal, Vol. 9, No. 1, Spring/Summer 1989, pp. 191-200; Jackman, W.T., The Development of Transportation in Modern England, Cambridge: Cambridge University Press, 1916; Klein, Dan, «The Voluntary Provision of Public Goods? The Turnpike Companies of Early America,» Economic Inquiry, October 1990, pp. 788-812; Klein, Dan, Majewski, J., and Baer, C., «Economy, Community and the Law: The Turnpike Movement in New York, 1797-1845, The Journal of Economic History, March 1993, pp. 106-122; Klein, Dan, Majewski, J., and Baer, C., «From Trunk to Branch: Toll Roads in New York, 1800-1860,» Essays in Economic and Business History, 1993, pp. 191-209; Klein, Dan and Fielding, G.J., «Private Toll Roads: Learning from the Nineteenth Century,» Transportation Quarterly, July 1992, pp. 321-341.; Klein, Dan and Fielding, G.J., «How to Franchise Highways,» Journal of Transport Economics and Policy, May 1993, pp. 113-130; Klein, Dan and Fielding, G.J., «High Occupancy/Toll Lanes: Phasing in Congestion Pricing a Lane at a Time,» Policy Study, No. 170, Reason Foundation, November 1993; Roth, Gabriel, The Private Provision of Public Services in Developing Countries, Oxford: Oxford University Press, 1987; Roth, Gabriel, Paying for Roads: The Economics of Traffic Congestion, Middlesex, England: Penguin, 1967; Roth, Gabriel, A Self-financing Road 
tivism,» you owe it to yourself to at least familiarize yourself with this literature.

Last but not least, why have I written an open letter to you, MADD, and not taken up my case with the authorities? For one thing, private organizations such as MADD are what has made this country great; government bureaucrats, operating way past their capacities, have always brought us down. For another, those presently in charge of our roadways are not just part of the problem, they pretty much are the problem. When and if a Nuremberg type trial is ever held for those responsible for thousands upon thousands of unnecessary traffic fatalities, these are the very people who will be prime candidates for occupancy in the dock.

MADD has a passion for saving lives. This, indeed, is what MADD is all about. That puts this organization head and shoulders above all others concerned with preserving life on our highways. But more is needed to be done. Far more. It is time for a radical departure from previous activity, in order, paradoxically, to build on previous good work. It is time for highway privatization, with MADD taking a lead role in this initiative.

System, London, England, The Institute of Economic Affairs, 1966; Rothbard, Murray N., For a New Liberty, Macmillan, New York, 1973; Woolridge, William C., Uncle Sam the Monopoly Man, New Rochelle, N.Y.: Arlington House, 1970. 